\title{
A healthy, sustainable and safe food system: examining the perceptions and role of the Australian policy actor using a Delphi survey
}

\author{
Sinead Boylan ${ }^{1} *$, Emma Sainsbury ${ }^{2}$, Anne-Marie Thow ${ }^{3}$, Christopher Degeling $^{4}$, \\ Luke Craven ${ }^{5}$, Darryl Stellmach ${ }^{6}$, Timothy P Gill ${ }^{2}$ and Ying Zhang ${ }^{1}$ \\ ${ }^{1}$ The University of Sydney, School of Public Health, Edward Ford Building, Sydney, NSW 2006, Australia: ${ }^{2}$ The \\ University of Sydney, Boden Institute of Obesity, Nutrition, Exercise and Eating Disorders, The Charles Perkins Centre, \\ Sydney, NSW, Australia: ${ }^{3}$ The University of Sydney, Menzies Centre for Health Policy, The Charles Perkins \\ Centre, Sydney, NSW, Australia: ${ }^{4}$ The University of Sydney, Sydney Health Ethics, Sydney School of Public Health, \\ Sydney, NSW, Australia: ${ }^{5}$ The University of Sydney, Sydney Environment Institute, The Charles Perkins Centre, \\ Sydney, NSW, Australia: ${ }^{\circ}$ The University of Sydney, The Charles Perkins Centre, Marie Bashir Institute and School of \\ Life and Environmental Sciences, Sydney, NSW, Australia
}

Submitted 25 October 2018: Final revision received 9 April 2019: Accepted 16 April 2019; First published online 25 July 2019

\begin{abstract}
Objective: There is an urgent need to identify and develop cross-sectoral policies which promote and support a healthy, safe and sustainable food system. To help shape the political agenda, a critical first step is a shared definition of such a system among policy makers across relevant sectors. The aim of the present study was to determine how Australian policy actors define, and contribute to, a healthy, safe and sustainable food system.

Design: A Delphi survey, consisting of two rounds, was conducted. Participants were asked how they define, and contribute to, a healthy, safe and sustainable food system (Round 1) and indicate their level of agreement with summary statements (Round 2).

Setting: This was an online Delphi survey conducted in Australia.

Participants: Twenty-nine and fourteen multisectoral and multilevel policy makers completed Round 1 and Round 2, respectively.

Results: The definition included food processing regulation, environmentally friendly food production and access to nutritious food. All agreed that it was important for them to improve access and supply of healthy food and ensure healthy planning principles are applied.

Conclusions: There were cross-sectoral differences in definitions and contributions; however, critical consensus was achieved. The study contributes to the definition of key elements of a cross-sectoral food and nutrition policy to meet today's environmental, health, social and economic challenges; however, further research using a more representative multisectoral sample is warranted.
\end{abstract}

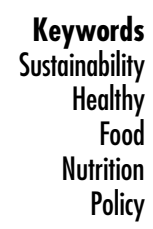

The food system encompasses all aspects of the production and movement of food, including growing, harvesting, processing, packaging, transport, marketing, consumption and disposal of food. The current global food system emerged in the 1950s, in part in response to the urgent need to produce enough food to feed the world's rapidly expanding population. The contemporary world, however, faces a new set of challenges such that the food system requires a radical rethink and redesign. These challenges are numerous, and environmental, economic, social and political in nature. Key concerns include climate change, reduced resources and loss of biodiversity, population growth and movement, food wastage, the proliferation of cheap energy-dense nutrient-poor foods (associated with multiple forms of malnutrition) and a disconnection of the general public from the food system more broadly ${ }^{(1-4)}$. Food systems underpin the 2030 Agenda for Sustainable Development, also known as the Sustainable Development Goals, which is a global commitment to eradicate poverty and hunger while ensuring environmental sustainability, health and 
prosperity for all ${ }^{(5)}$. Food and agriculture have a role to play in most, if not all, of the seventeen goals, with Goal 2 specifically devoted to end hunger and malnutrition, achieve food security and improved nutrition, and promote sustainable agriculture ${ }^{(5)}$. Tackling food system challenges will mean that we need to address the gaps in understanding of what a sustainable food system means across varying populations and geographies, and will require an integrated approach if we are to meet many of the Sustainable Development Goals.

Because the food system is contingent on human activities on a range of scales and locations, the relationship between it and the environment (natural, social and economic) is complex and by no means unidirectional. Poor diet is now identified as the leading preventable risk factor for the global burden of disease, overtaking tobacco use ${ }^{(6)}$. Regarding planetary health, agricultural food production (and associated land-use change) substantially contributes to greenhouse gas emissions worldwide, with the livestock sector contributing four-fifths of agricultural emissions ${ }^{(7)}$. This situation is likely to worsen, as we try to produce and process enough food to meet the needs of the world's growing population who increasingly demand animal-derived protein ${ }^{(8)}$. However, examining the impact of our food system more broadly highlights the complexities further. For example, one could argue that industrialisation of our food system has supported economic and social sustainability. Industrialised processes may have improved food producers' profitability and, therefore, their livelihoods and the prosperity of their communities ${ }^{(9)}$. Contra to this vision of beneficial development, others have argued that the current food system places enormous strain on food producers to supply products which meet strict cosmetic standards and food price reductions while grappling with diminishing resources ${ }^{(10)}$.

The present research focuses on Australia, where the food system faces many of the aforementioned challenges $^{(11-14)}$. For example, Australia is one of the most vulnerable developed countries to the impacts of climate change $^{(12)}$. Climate change is anticipated to reduce food production in Australia by more than $15 \%$ over the next 40 years $^{(15)}$. Rising temperatures and increases in extreme weather events such as droughts, flooding and fires, all threaten Australia's food system ${ }^{(12)}$. On top of this, valuable resources such as arable land and farmers themselves vital ingredients for a healthy, safe and sustainable food system - are disappearing in Australia ${ }^{(12,16)}$ even as food insecurity persists. Food security requires constant access to sufficient, safe, nutritious food to maintain a healthy and active life ${ }^{(17)}$; however, over one-fifth of Indigenous populations in Australia reported to be food insecure (that they had run out of food at least once in the past 12 months and were unable to buy more) ${ }^{(18)}$. Yet despite these issues, Australia continues to remain a powerful food producer, with food production accounting for about $30 \%$ of its ecological footprint ${ }^{(19)}$. Australia is also in urgent need of an updated national nutrition policy.
There is an urgent need to identify and implement strategies to promote and support healthy and sustainable diets, in Australia and globally ${ }^{(20)}$. From an international perspective, FAO defines a healthy, sustainable, safe food system as one which 'provides healthy food to meet current food needs while maintaining healthy ecosystems that can also provide food for generations to come with minimal negative impact to the environment. A sustainable food system also encourages local production and distribution infrastructures and makes nutritious food available, accessible, and affordable to all. Further, it is humane and just, protecting farmers and other workers, consumers, and communities' ${ }^{\text {(20). }}$.

In Australia, there is currently no comprehensive policy which maps out actions to promote a healthy, sustainable and safe food system ${ }^{(14)}$. However, in order to shape the political agenda, an agreement on the definition of such a system is needed ${ }^{(21)}$. It is also important that there is a better understanding of the political dynamics of this system ${ }^{(22)}$. Against this background, the present study has two objectives: (i) to determine how Australian policy actors from relevant sectors define a healthy, sustainable and safe food system; and (ii) to assess how policy actors from different government sectors contribute to a healthy, sustainable and safe food system. The results of this survey will be used to inform and create opportunities for a muchneeded system-wide policy approach to promoting positive outcomes in the food system in Australia.

\section{Methods}

A modified Delphi technique was used to poll multisectoral policy makers across local, state and federal institutions. The Delphi method is a structured, iterative process of collecting opinions and providing controlled feedback ${ }^{(23,24)}$ and is deemed a useful method to reach a consensus on complex issues among a panel of experts. The Delphi technique has been used in a wide range of research and more recently in identifying sustainability indicators of food systems and $\operatorname{diets}^{(25)}$. The Delphi technique was the current study's method of choice as it is rigorous for expert queries ${ }^{(26)}$, flexible $^{(27)}$ and anonymous ${ }^{(28)}$. In the current study, we modified the Delphi technique to allow for a qualitative analysis of participants' views and explore areas of consensus and disagreement among participants. In addition, we quantitatively examined consensus of opinions by defining critical consensus as $>80 \%$ of respondents agreeing with a particular statement ${ }^{(23)}$.

\section{Delphi participants}

Delphi panels are considered valid when they consist of between fifteen and sixty experts ${ }^{(29)}$. A targeted approach was taken to elicit information from stakeholders likely to be knowledgeable about the topic. Cross-disciplinary experts from The University of Sydney were asked to 
provide contact details for key policy actors across government sectors at the federal, state/territory and local government levels. In addition, an Internet search was conducted to retrieve participant contact details available in the public domain, with the aim to ensure a wide geographical spread and representation of all relevant government sectors (e.g. health, environment, agriculture, foreign affairs and trade, primary industries, infrastructure and planning, regional development). A secure Microsoft ${ }^{\circledR}$ Excel database was used to record each participant's name, email address, work organisation and role. Using snowballing sampling ${ }^{(30)}$, participants were invited to forward the recruitment email and survey link to other policy makers within their sector who might be interested in participating in the study.

\section{Data collection}

A two-round Delphi survey, hosted through the online software package Qualtrics ${ }^{\circledR}$, was conducted from February to May 2017. In Round 1, a recruitment email was sent to all participants with an outline of the study objectives, a Participant Information sheet and a link to an online survey. An anonymous link was used, allowing the survey to be forwarded on to other policy actors. The Round 1 survey asked participants to respond to three open-ended questions: "What does the term "healthy, sustainable and safe food system" mean to you in your current role? (Question 1); 'In what ways does your current role contribute to a healthy, sustainable and safe food system?' (Question 2); and 'In your current role, what barriers and enablers are there to ensuring a healthy, sustainable and safe food system?' (Question 3). Participants were also asked to answer three questions regarding their work location, organisation and role so that responses could be matched to contact details in the Excel database.

All participants identified has having completed Round 1 were emailed and invited to take part in the Round 2 survey. Policy actors who indicated they forwarded the Round 1 survey to others in their department were also emailed the Round 2 survey link with a request to forward on to any respondents. The email explicitly stated that the Round 2 survey was to be completed only by those who had responded in Round 1. Participants were asked to indicate their level of agreement with summary statements from Round 1 on a 5-point Likert scale (Questions 1 and 3: 'strongly agree' to 'strongly disagree'; Question 2: 'very important' to not 'important'). To increase the participant response rate, surveys were kept online for up to 3 weeks, and a reminder email was sent out to all policy actors approximately $7 \mathrm{~d}$ after the initial invitation.

\section{Data analysis}

One author (E.S.) reviewed the qualitative responses from Round 1, extracting and grouping similar statements together. For each group of statements, a summary statement was produced for inclusion in the Round 2 survey.
Unique statements that did not fall within a group were also directly included in Round 2. Sector-specific analyses of responses to Questions 1 and 2 in Round 1 were also conducted by grouping responses from policy actors working in the same department to examine differences and similarities in definitions and contributions by sector. Anonymous raw data and summary statements were cross-checked by all authors to ensure accurate representation of responses.

Results from the Round 2 survey were entered into the statistical software package IBM SPSS Statistics for Windows $^{\circledR}$ version 22.0 (2013). Each statement was set up as a categorical variable, with scores allocated for participant responses ( 1 = 'strongly agree'/'very important' to $5=$ 'strongly disagree'/"not important'). Descriptive statistics were run to identify statements that reached critical consensus ${ }^{(23)}$. For Questions 1 and 3, the percentage of participants in agreement (either strongly or somewhat) was calculated for each statement and totalled. For Question 2 which asked participants to indicate how important they consider each statement, the percentage of participants that considered each statement important or very important was calculated and totalled. As with Questions 1 and 3, critical consensus was considered achieved when there was a total of $>80 \%$ agreement among respondents.

\section{Results}

\section{Delphi survey participant characteristics}

Of 225 policy actors contacted, nine excluded themselves from the Round 1 survey on the basis of time restrictions, four excluded themselves as they perceived the subject of the survey to be outside their work remit and 173 provided no response. Thirty-nine policy actors accessed the Round 1 Delphi survey. Of these, twenty-nine (12.9\%) provided a complete response and one policy actor provided a partial response. Partial responses were excluded from analysis ( $n$ 1). Thirteen participants excluded themselves on the basis of time restrictions or inadequate expertise. As illustrated in Table 1, participants were from a range of geographic locations and government sectors, but the majority of respondents (69.0\% in Round 1) worked within a state/territory health department. Policy actors from New South Wales and Tasmania were the most likely to respond to the survey, with response rates of 33.3 and $26.7 \%$, respectively (Table 1 ). Forty-eight per cent of respondents listed job titles of 'senior officer', 'team leader', 'manager', 'director' or 'chief executive officer (CEO)', indicating a high level of experience and expertise in the field. In Round 1, twenty-nine responses were provided for Question 1, and twenty-eight responses to Questions 2 and 3. Qualitative responses to the three open-ended questions in Round 1 were thematically analysed and a set of summary statements generated, as shown in Tables 2-5. The Round 2 survey was emailed to all respondents from Round 1 and yielded a $48.3 \%$ ( $n$ 14) response rate. 
Table 1 Characteristics of the Delphi survey participants, Australia, February-May 2017

\begin{tabular}{|c|c|c|c|}
\hline Characteristic & $\begin{array}{l}\text { Contacted to } \\
\text { participate } \\
(n)\end{array}$ & $\begin{array}{l}\text { Round } 1 \\
\text { response } \\
(n)\end{array}$ & $\begin{array}{c}\text { Round } 2 \\
\text { response } \\
(n)\end{array}$ \\
\hline Number of policy actors & 225 & 29 & 14 \\
\hline \multicolumn{4}{|l|}{ Location } \\
\hline Victoria & 31 & 2 & 2 \\
\hline Queensland & 19 & 4 & 3 \\
\hline South Australia & 17 & 3 & 1 \\
\hline Northern Territory & 19 & 3 & 2 \\
\hline Western Australia & 32 & 2 & 0 \\
\hline $\begin{array}{l}\text { Australian Capital } \\
\text { Territory }\end{array}$ & 19 & 0 & 0 \\
\hline Tasmania & 18 & 6 & 1 \\
\hline Federal & 40 & 1 & 1 \\
\hline \multicolumn{4}{|l|}{ Level of government } \\
\hline Federal & 39 & 1 & 1 \\
\hline State & 176 & 27 & 12 \\
\hline Local & 10 & 1 & 1 \\
\hline \multicolumn{4}{|l|}{ Government department } \\
\hline Health & 82 & 20 & 11 \\
\hline Environment and energy & 52 & 1 & 0 \\
\hline $\begin{array}{l}\text { Economic and regional } \\
\text { development }\end{array}$ & 27 & 0 & 0 \\
\hline $\begin{array}{l}\text { Agriculture and water } \\
\text { resources }\end{array}$ & 19 & 3 & 1 \\
\hline Primary industries & 18 & 4 & 1 \\
\hline $\begin{array}{l}\text { Infrastructure and } \\
\text { planning }\end{array}$ & 14 & 1 & 1 \\
\hline Foreign affairs and trade & 10 & 0 & 0 \\
\hline $\begin{array}{l}\text { Aboriginal and } \\
\text { community affairs }\end{array}$ & 3 & 0 & 0 \\
\hline \multicolumn{4}{|l|}{ Discipline } \\
\hline Environmental health & & 8 & 3 \\
\hline Nutrition and dietetics & & 4 & 3 \\
\hline Health promotion & & 3 & 1 \\
\hline Health policy & & 2 & 2 \\
\hline $\begin{array}{l}\text { Food safety and } \\
\text { regulation }\end{array}$ & & 2 & 1 \\
\hline Marine health & & 1 & 1 \\
\hline Environmental regulation & & 2 & 0 \\
\hline Agricultural economics & & 2 & 0 \\
\hline Veterinary sciences & & 2 & 1 \\
\hline $\begin{array}{l}\text { Planning and urban } \\
\text { design }\end{array}$ & & 1 & 1 \\
\hline Not specified & & 2 & 1 \\
\hline
\end{tabular}

Similar to Round 1, the majority of respondents (78.6\%) worked within a state/territory health department and $43.0 \%$ held senior positions in their organisation.

\section{Definition of a bealthy, sustainable and safe food system}

\section{Round 1: Sector-specific definitions}

Sector-specific analysis was conducted on the Round 1 survey responses only as the Round 2 sample size would not allow for any meaningful similar analyses. Sectorspecific analysis of Round 1 responses revealed variation in the perceived definition of a healthy, sustainable and safe food system between government departments. Food processing and consumption were the foci of definitions provided by respondents from the health and planning sectors, in particular ensuring consumers have access to food that is nutritious, fresh and safe, e.g. 'it means that people have access to a healthy (in line with the Australian Dietary Guidelines), sustainable (2 parts to this a reliable supply chain and foods that is environmentally sustainable) and safe (free from pollutants and stored correctly) food system'. Although definitions provided by policy actors from the environment, primary industries and agriculture departments highlighted the need to produce food that is of high quality and safe for human consumption, e.g. 'a system that can, with a high degree of confidence, assure consumers of low risk of toxins, residues and minimal risk of diseases through consuming food products', there was a stronger focus on producing food in a way that is sensitive to the natural environment, e.g. 'the context in which I think about the term is whether the food was produced in a manner that was at least environmentally neutral ... or ideally the food was produced by methods that improved the environment during the entire production process'.

\section{Round 2: Cross-sectoral definitions}

In Round 2, respondents agreed upon three definitions of a healthy, sustainable and safe food system (Table 2). These definitions related to food processing regulation, environmentally friendly food production and nutritious food access. None of the respondents strongly agreed with the definition 'A system that promotes eating plant-based foods over animal foods'.

\section{Contribution of policy actors to a bealtby, sustainable and safe food system}

\section{Round 1: Sector-specific contributions}

In Round 1, policy actors identified a number of ways in which their current work roles contribute to a healthy, sustainable and safe food system. The contributions of the health and planning sectors were evident across the food system from food processing, packaging, transport, marketing and consumption, e.g. 'My role (and others within public health) work at a number of levels from informing policy (food security), industry (food labelling), public safety (health messages/warnings/regulations), workforce development (communication/health messaging/ resource development), education ... to working with communities to create supportive environments to build individual and community health literacy'. Interestingly, there was variation in responses across different disciplines within the health sector. The contribution of policy actors working in the areas of environmental health and food safety included the development and enforcement of food safety regulations, while public health nutritionists, dietitians and policy actors working in health promotion focused on providing education and access to healthy food. Policy actors from the primary industries, 
Table 2 Definitions of a healthy, sustainable and safe food system, ranked by level of agreement (Round 2, $n$ 14), Australia, February-May 2017

\begin{tabular}{|c|c|c|c|c|c|c|}
\hline Definition & $\begin{array}{l}\text { Strongly } \\
\text { agree (\%) }\end{array}$ & $\begin{array}{l}\text { Somewhat } \\
\text { agree }(\%)\end{array}$ & $\begin{array}{c}\text { Neither agree } \\
\text { nor disagree (\%) }\end{array}$ & $\begin{array}{c}\text { Somewhat } \\
\text { disagree (\%) }\end{array}$ & $\begin{array}{l}\text { Disagree } \\
(\%)\end{array}$ & $\begin{array}{c}\text { Total } \\
\text { agree } \\
(\%)\end{array}$ \\
\hline $\begin{array}{l}\text { A system where the processing, labelling and handling } \\
\text { of food meets regulatory requirements }\end{array}$ & $35 \cdot 7$ & $50 \cdot 0$ & $14 \cdot 3$ & 0.0 & 0.0 & $85 \cdot 7^{*}$ \\
\hline $\begin{array}{l}\text { A system where food production does not damage or } \\
\text { deplete the environment }\end{array}$ & $35 \cdot 7$ & $50 \cdot 0$ & $14 \cdot 3$ & 0.0 & 0.0 & $85 \cdot 7^{*}$ \\
\hline $\begin{array}{l}\text { A system that provides access to nutritious food, in } \\
\text { line with the Australian Dietary Guidelines }\end{array}$ & $35 \cdot 7$ & $50 \cdot 0$ & $7 \cdot 1$ & 0.0 & $7 \cdot 1$ & $85 \cdot 7^{*}$ \\
\hline $\begin{array}{l}\text { A system where food is accessible, affordable and } \\
\text { culturally appropriate for all Australians }\end{array}$ & $35 \cdot 7$ & $42 \cdot 9$ & $14 \cdot 3$ & 0.0 & 0.0 & 78.6 \\
\hline $\begin{array}{l}\text { A system that supports the consumption of fresh, } \\
\text { seasonal, locally produced food }\end{array}$ & $35 \cdot 7$ & $42 \cdot 9$ & 0.0 & 21.4 & 0.0 & $78 \cdot 6$ \\
\hline $\begin{array}{l}\text { A system that ensures a sufficient volume of food for } \\
\text { future generations }\end{array}$ & $35 \cdot 7$ & $28 \cdot 6$ & $28 \cdot 6$ & $7 \cdot 1$ & 0.0 & $64 \cdot 3$ \\
\hline $\begin{array}{l}\text { A system that provides access to food free of } \\
\text { chemical and biological contamination and disease }\end{array}$ & $28 \cdot 6$ & $35 \cdot 7$ & $28 \cdot 6$ & $7 \cdot 1$ & 0.0 & $64 \cdot 3$ \\
\hline $\begin{array}{l}\text { A system where food production is ethical and } \\
\text { considers the needs of producers }\end{array}$ & 21.4 & $50 \cdot 0$ & $14 \cdot 3$ & $14 \cdot 3$ & 0.0 & 71.4 \\
\hline $\begin{array}{l}\text { A system that supports economic prosperity of the } \\
\text { primary industries and food sector }\end{array}$ & $14 \cdot 3$ & $57 \cdot 1$ & 21.4 & $7 \cdot 1$ & 0.0 & $71 \cdot 4$ \\
\hline $\begin{array}{l}\text { A system that promotes eating plant-based foods over } \\
\text { animal foods }\end{array}$ & 0.0 & $35 \cdot 7$ & $14 \cdot 3$ & $14 \cdot 3$ & $35 \cdot 7$ & $35 \cdot 7$ \\
\hline
\end{tabular}

Table 3 Contribution of policy actors to ensuring a healthy, sustainable and safe food system, ranked by level of importance (Round 2, $n$ 14), Australia, February-May 2017

\begin{tabular}{|c|c|c|c|c|c|c|}
\hline Contribution of policy actors & $\begin{array}{l}\text { Very } \\
\text { important } \\
(\%)\end{array}$ & $\begin{array}{l}\text { Important } \\
(\%)\end{array}$ & $\begin{array}{l}\text { Somewhat } \\
\text { important (\%) }\end{array}$ & $\begin{array}{l}\text { Not } \\
\text { important } \\
(\%)\end{array}$ & $\begin{array}{c}\text { Don't } \\
\text { know (\%) }\end{array}$ & $\begin{array}{l}\text { Total } \\
\text { important } \\
(\%)\end{array}$ \\
\hline $\begin{array}{l}\text { Working to improve access/supply of healthy } \\
\text { food within communities }\end{array}$ & $50 \cdot 0$ & $50 \cdot 0$ & 0.0 & 0.0 & 0.0 & $100 \cdot 0^{*}$ \\
\hline $\begin{array}{l}\text { Ensuring healthy planning principles are applied } \\
\text { in relevant planning policy and legislation }\end{array}$ & $42 \cdot 9$ & $57 \cdot 1$ & 0.0 & 0.0 & 0.0 & $100 \cdot 0^{*}$ \\
\hline Ensuring sustainable use of environmental resources & $42 \cdot 9$ & $57 \cdot 1$ & 0.0 & 0.0 & 0.0 & $100 \cdot 0^{*}$ \\
\hline $\begin{array}{l}\text { Implementing and enforcing policies around the } \\
\text { preparation, handling, packaging and labelling } \\
\text { of foods }\end{array}$ & $35 \cdot 7$ & $57 \cdot 1$ & $7 \cdot 1$ & 0.0 & 0.0 & $92 \cdot 9^{*}$ \\
\hline $\begin{array}{l}\text { Disease surveillance and investigation of food-borne } \\
\text { outbreaks }\end{array}$ & $57 \cdot 1$ & $28 \cdot 6$ & $14 \cdot 3$ & $0 \cdot 0$ & 0.0 & $85 \cdot 7^{*}$ \\
\hline Building individual and community health literacy & $42 \cdot 9$ & $42 \cdot 9$ & $14 \cdot 3$ & 0.0 & 0.0 & $85 \cdot 7^{*}$ \\
\hline Advocating for change in food industry behaviours & 35.7 & $50 \cdot 0$ & $14 \cdot 3$ & 0.0 & 0.0 & $85 \cdot 7^{\star}$ \\
\hline $\begin{array}{l}\text { Implementing guidelines for settings (e.g. schools, } \\
\text { sports clubs, health facilities) to ensure provision } \\
\text { of food that meets Australian Dietary Guidelines }\end{array}$ & $28 \cdot 6$ & $57 \cdot 1$ & $14 \cdot 3$ & 0.0 & 0.0 & $85 \cdot 7^{*}$ \\
\hline $\begin{array}{l}\text { Developing programmes to improve economic } \\
\text { development in the primary production sector }\end{array}$ & $7 \cdot 1$ & $64 \cdot 3$ & $28 \cdot 6$ & 0.0 & 0.0 & 71.4 \\
\hline
\end{tabular}

${ }^{*}$ Critical consensus was reached $(>80 \%$ agreement).

environment and agriculture sectors contributed to a healthy, safe and sustainable food system at the stage of food production, including promoting healthy farming principles, ensuring sustainable resource use, and disease prevention and surveillance. Responses from the primary industries also revealed a focus on promoting economic growth, e.g. 'I am currently responsible for developing new initiatives, programmes and projects that improve economic development in the primary production sector'.

\section{Round 2: Cross-sectoral contributions}

In Round 2, all of the respondents agreed that policy actors had an important role in 'working to improve access and supply of healthy foods within communities', 'ensuring healthy planning principles are applied in relevant planning policy and legislation' and 'ensuring sustainable use of environmental resources'. There was a critical consensus (>80\% agreement) that policy actors had an important role in implementing policies regarding food preparation, handling, packaging and labelling, as well as food safety, 
Table 4 Barriers to ensuring a healthy, sustainable and safe food system, ranked by level of agreement (Round 2, $n$ 14), Australia, February-May 2017

\begin{tabular}{|c|c|c|c|c|c|c|}
\hline Barriers & $\begin{array}{l}\text { Strongly } \\
\text { agree } \\
(\%)\end{array}$ & $\begin{array}{l}\text { Somewhat } \\
\text { agree (\%) }\end{array}$ & $\begin{array}{l}\text { Neither agree } \\
\text { nor disagree } \\
(\%)\end{array}$ & $\begin{array}{l}\text { Somewhat } \\
\text { disagree } \\
(\%)\end{array}$ & $\begin{array}{l}\text { Strongly } \\
\text { disagree } \\
(\%)\end{array}$ & $\begin{array}{l}\text { Total } \\
\text { agree } \\
(\%)\end{array}$ \\
\hline Conflicting agendas between stakeholders & $64 \cdot 3$ & $28 \cdot 6$ & 0.0 & $7 \cdot 1$ & 0.0 & $92 \cdot 9^{*}$ \\
\hline Lack of awareness and understanding by consumers & $35 \cdot 7$ & $57 \cdot 1$ & $7 \cdot 1$ & 0.0 & 0.0 & $92 \cdot 9^{*}$ \\
\hline $\begin{array}{l}\text { Limited regulation of the food industry (e.g. no restrictions } \\
\text { on advertising of junk food) }\end{array}$ & $35 \cdot 7$ & $42 \cdot 9$ & $7 \cdot 1$ & $7 \cdot 1$ & $7 \cdot 1$ & $78 \cdot 6$ \\
\hline $\begin{array}{l}\text { Environmental sustainability not focused on in the } \\
\text { Australian Dietary Guidelines }\end{array}$ & $28 \cdot 6$ & $42 \cdot 9$ & $14 \cdot 3$ & $14 \cdot 3$ & 0.0 & 71.5 \\
\hline $\begin{array}{l}\text { Conflicts over existing evidence around what is healthy } \\
\text { and sustainable }\end{array}$ & $14 \cdot 3$ & $57 \cdot 1$ & $14 \cdot 3$ & $14 \cdot 3$ & 0.0 & $71 \cdot 4$ \\
\hline $\begin{array}{l}\text { Current efforts to achieve a healthy, sustainable and safe } \\
\text { food system are isolated }\end{array}$ & $14 \cdot 3$ & $42 \cdot 9$ & $42 \cdot 3$ & 0.0 & 0.0 & $57 \cdot 2$ \\
\hline Affordability of healthy food $v$. processed food & $42 \cdot 9$ & $21 \cdot 4$ & $7 \cdot 1$ & $14 \cdot 3$ & $14 \cdot 3$ & $64 \cdot 3$ \\
\hline $\begin{array}{l}\text { No common goal for stakeholders to work towards } \\
\text { (e.g. no national nutrition policy to guide direction) }\end{array}$ & $35 \cdot 7$ & $28 \cdot 6$ & $7 \cdot 1$ & $21 \cdot 4$ & $7 \cdot 1$ & $64 \cdot 3$ \\
\hline Limited funding and resources & $21 \cdot 4$ & $35 \cdot 7$ & $21 \cdot 4$ & 21.4 & 0.0 & $57 \cdot 1$ \\
\hline $\begin{array}{l}\text { Limited representation of people with knowledge in healthy } \\
\text { food environments in decision-making and advisory } \\
\text { groups }\end{array}$ & $14 \cdot 3$ & $42 \cdot 9$ & $28 \cdot 6$ & $7 \cdot 1$ & $7 \cdot 1$ & $57 \cdot 2$ \\
\hline $\begin{array}{l}\text { Difficulty in changing producers' large-scale farming } \\
\text { techniques }\end{array}$ & $7 \cdot 1$ & 35.7 & $42 \cdot 9$ & $14 \cdot 3$ & 0.0 & $42 \cdot 9$ \\
\hline $\begin{array}{l}\text { Ongoing development of new food products and new } \\
\text { entrants to the food-service sector }\end{array}$ & $7 \cdot 1$ & 0.0 & $50 \cdot 0$ & $42 \cdot 9$ & 0.0 & $7 \cdot 1$ \\
\hline
\end{tabular}

${ }^{*}$ Critical consensus was reached $(>80 \%$ agreement).

Table 5 Enablers to ensuring a healthy, sustainable and safe food system, ranked by level of agreement (Round 2, $n$ 14), Australia, February-May 2017

\begin{tabular}{|c|c|c|c|c|c|c|}
\hline Enablers & $\begin{array}{l}\text { Strongly } \\
\text { agree (\%) }\end{array}$ & $\begin{array}{l}\text { Somewhat } \\
\text { agree (\%) }\end{array}$ & $\begin{array}{l}\text { Neither agree } \\
\text { nor disagree } \\
(\%)\end{array}$ & $\begin{array}{c}\text { Somewhat } \\
\text { disagree } \\
(\%)\end{array}$ & $\begin{array}{l}\text { Strongly } \\
\text { disagree } \\
(\%)\end{array}$ & $\begin{array}{c}\text { Total } \\
\text { agree } \\
(\%)\end{array}$ \\
\hline Australia's relatively safe and accessible food supply & $42 \cdot 9$ & $57 \cdot 1$ & $0 \cdot 0$ & $0 \cdot 0$ & 0.0 & $100 \cdot 0^{*}$ \\
\hline $\begin{array}{l}\text { Growing public and political awareness and support for } \\
\text { creation of healthy food environments }\end{array}$ & $57 \cdot 1$ & $35 \cdot 7$ & $7 \cdot 1$ & $0 \cdot 0$ & $0 \cdot 0$ & $92 \cdot 9^{*}$ \\
\hline Confidence in Australia's food regulation standards & $42 \cdot 9$ & $42 \cdot 9$ & $14 \cdot 3$ & 0.0 & 0.0 & $85 \cdot 8^{*}$ \\
\hline $\begin{array}{l}\text { Australian Dietary Guidelines support a healthy, } \\
\text { sustainable diet }\end{array}$ & $28 \cdot 6$ & $57 \cdot 1$ & $14 \cdot 3$ & $0 \cdot 0$ & $0 \cdot 0$ & $85 \cdot 7^{*}$ \\
\hline $\begin{array}{l}\text { The actions of non-government sectors, academics and } \\
\text { advocates that bring attention to this issue }\end{array}$ & $21 \cdot 4$ & $57 \cdot 1$ & $14 \cdot 3$ & $7 \cdot 1$ & 0.0 & $78 \cdot 6$ \\
\hline Good relationships with stakeholders & $28 \cdot 6$ & $42 \cdot 9$ & $28 \cdot 6$ & 0.0 & 0.0 & 71.4 \\
\hline $\begin{array}{l}\text { Good level of food knowledge within the community (e.g. } \\
\text { where food comes from and how to prepare it) }\end{array}$ & $21 \cdot 4$ & $42 \cdot 9$ & $14 \cdot 3$ & 21.4 & 0.0 & $64 \cdot 3$ \\
\hline
\end{tabular}

${ }^{*}$ Critical consensus was reached $(>80 \%$ agreement).

sustainable resource use, health literacy, advocacy and implementation of dietary guidelines.

\section{Barriers and enablers faced by policy actors}

Twelve barriers to promoting a healthy, sustainable and safe food system were extracted from the Round 1 survey responses and a critical consensus ( $92.9 \%$ agreement) was reached on two of these in the second survey round (Table 4): 'Conflicting agendas between stakeholders' and 'Lack of awareness and understanding by consumers'. As observed in Questions 1 and 2, there was variation between government departments in the barriers to ensuring a healthy, sustainable and safe food system. The most common barriers reported by health sector respondents were: poor consumer understanding of what is healthy; no inclusion of sustainability in the Australian Dietary Guidelines; absence of government regulation (e.g. nutrition policy); and conflicting agendas between the health sector and food industry. Respondents from primary industries, agriculture and environment departments identified similar barriers but within the earlier stages of food production, including lack of government resources and retail demand for quantity over quality.

Seven enablers to promoting a healthy, sustainable and safe food system were extracted from the Round 1 qualitative survey responses. The majority of these were provided by health sector respondents, with policy actors from the agriculture and environment sectors identifying no 
enablers. In Round 2, critical consensus was reached on four of the seven enablers, including Australia's safe and accessible food supply, growing awareness and support, regulation and the current dietary guidelines (Table 5).

\section{Discussion}

The present study is the first to examine policy actors' understanding of a healthy, safe and sustainable food system in Australia. There was general consensus among respondents that key issues for defining such a food system focused on compliance with regulation (i.e. food safety), environmentally sustainable production and access to nutritious food. Regarding ways in which policy actors could contribute to ensuring a healthy, safe and sustainable food system, consensus was reached on all but one of the strategies identified (i.e. 'Developing programmes to improve economic development in the primary production sector'). Contradictions existed between identified barriers and enablers in achieving a healthy and sustainable food system. The preponderance of responses from state-level policy actors might reflect the state-level responsibilities in Australia's federated government for relevant policy areas, such as land/urban planning, transport, health care and environmental health. State governments in Australia have also been leading action on nutrition and obesity, in the absence of national policy frameworks.

\section{Defining a bealthy, sustainable and safe food system}

In the current study, the definitions selected by respondents for a healthy, sustainable and safe food system covered all of the key issues of nutrition, environmental sustainability and food safety. A nutritionally adequate diet was recognised by respondents as one which complies with the recommendations of the Australian Dietary Guidelines; i.e. one which encourages consumption of core foods including vegetables, fruits, meat, dairy, and breads and cereals, and discourages consumption of energy-dense nutrient-poor discretionary foods ${ }^{(31)}$. While Australian research shows that reduced consumption of discretionary foods is associated with lower production of greenhouse gas emissions ${ }^{(32)}$, the production of meat and dairy products has a huge environmental impact. Rearing of livestock for meat, eggs and milk generates $14.5 \%$ of total global greenhouse gas emissions and utilises $70 \%$ of agricultural land ${ }^{(33)}$. It was of interest to note that among policy actors surveyed in the present study, just over one-third agreed that a healthy, safe and sustainable diet was in line with consuming a plant-based diet. This is in contrast to studies of consumers conducted in Europe, where policy actors and consumers perceive little difference between a healthy and sustainable diet and a plant-based diet ${ }^{(34,35)}$. The findings from the current study may reflect the large proportion of respondents who identified as nutrition professionals working within the health-care sector, who are likely to promote the inclusion of all five food groups in a healthy diet in line with Australian Dietary Guideline recommendations. In addition, the higher representation of health professionals may have contributed to the critical consensus on two of the three definitions associated with human health. A qualitative survey assessing consumer perceptions of the match, or mismatch, between healthy and sustainable diets indicates that consumers also attach greater importance to human health-related aspects of food compared with environmental sustainability ${ }^{(35)}$; therefore, it might be useful to frame future actions to achieve a healthy, safe and sustainable food system using a health lens.

However, the definitions which gained strongest support from Delphi participants appeared to lack the holistic narrative of the $\mathrm{FAO}^{(20)}$. Considering generations to come, local and ethical production, availability and affordability did gain reasonable $(64.3,78.6$ and $78.6 \%$ agreement, respectively) but not a predefined critical consensus (>80\% agreement) among the respondents. These components are especially important in Australia, where: the population continues to grow faster than the global average $^{(36)}$; local food supplies, which once dominated the food system, have been replaced by much longer supply chains $^{(37)}$; food insecurity exists at disproportionately high rates among sub-populations ${ }^{(18)}$; and the number of farmers has been declining over the decades ${ }^{(16)}$.

A review conducted in the UK highlighted how broad and complex a healthy, sustainable and safe food system is to define, and the fact that difficulties in addressing the problem arise because 'stakeholders prioritize the dimensions of sustainability in different ways ${ }^{\text {(38) }}$, whether it be environmental, social or economic. Moreover, the level on which the policy community, in particular, agrees on the definition of, causes of and solutions to the problem can shape political priority $^{(21)}$. There were differences in definitions evident across sectors in the results of the current survey. Those working within the health sector are trained in protecting the consumer and/or promoting health of the consumer, therefore it is of no surprise that the findings indicate their perception of a healthy, sustainable and safe food system is generally one which ensures population access to healthy, safe, fresh food. Definitions offered by the those working in the environment sector reveal very different priorities of environmental sustainability. Despite these sectoral differences, there was critical consensus that the definition includes food processing regulation, environmentally friendly food production and access to nutritious foods. This offers some hope in developing a systems-wide policy to promote a healthy, safe and sustainable food system.

\section{Contribution of Australian policy actors to ensuring a bealthy, sustainable and safe food system}

The findings of the current study regarding roles and responsibilities indicate that participants, who were mostly 
from the health sector, did see it as their responsibility to promote a healthy, sustainable and safe food system, despite any differences in how they define such a system. One of the most important contributions perceived by policy actors is working to improve access and supply to healthy food. Current policies to improve healthy food access and supply in Australia include mandatory food standards for settings such as schools and health facilities and the Healthy Food Partnership supporting food industry to reformulate its foods to support healthier diets; however, the partnership is voluntary in nature ${ }^{(39,40)}$. Fiscal policies can also support access to healthy food ${ }^{(40)}$; however, economic strategies do not appear to be considered part of the respondents' preferred range of strategies in contributing to a healthy, safe and sustainable food system.

The other role which gained strong consensus among respondents regarded urban planning polices and legislations. There has been a growing movement in this space within Australia. For example, the National Heart Foundation of Australia released the document FoodSensitive Planning and Urban Design: A Conceptual Framework for Achieving a Sustainable and Healthy Food System ${ }^{(41)}$ which considers ways of protecting our food system in the face of urbanisation. Australian local governments are also developing planning policies to improved food access within their boundaries ${ }^{(41)}$. While this is encouraging, planning policies to improved access to healthy food in Australia are lacking at a jurisdictional or national level.

Despite the lack of a holistic definition among respondents, it was encouraging to find a consensus that respondents could contribute to a healthy, sustainable and safe food system right through the food system, from production (sustainable environmental resource use) to processing (advocating for change in food industry, enforcing policies for preparation, handling, packaging, labelling and surveillance of outbreaks) and to consumption (health literacy). Sector-specific analysis revealed obvious variation in policy actor contributions, with government departments contributing at different stages of the food system. Saying this, it was encouraging that there was a critical consensus regarding all contributions, indicating that a coordinated action between sectors may be possible.

A national policy could support policy makers across sectors in their contribution towards a healthy, safe and sustainable food system. Australia's Department of Agriculture and Water Resources introduced a National Food Plan; however, this was replaced by an Agricultural Competitiveness White Paper in 2015 which references an objective of sustainable food production practices but identifies no initiatives to achieve this ${ }^{(42)}$. While the goal is to produce food sustainably by 2025 , there exists a strong focus on developing a 'competitive, productive food industry'. The National Food Plan has been criticised due to the influence on its development by powerful industry groups and the resulting side-lining of nutrition and sustainability ${ }^{(43)}$. In addition, Australia's National Nutrition Policy is outdated ${ }^{(44)}$ and the Australian Dietary Guidelines downplay the importance of sustainable dietary patterns by referring to such patterns in an appendix only ${ }^{(45)}$. A national alliance of people and organisations in Australia has developed The People's Food Plan to support the development a food system which prioritises health and ecosystem integrity, as well as sustainable agricultural methods ${ }^{(46)}$.

Across the European Union, policies have been introduced to promote a healthy, sustainable food system ${ }^{(35)}$. Recently in the UK, different civil society organisations, unions and community groups working across the food system have come together to develop The People's Food Policy, an integrated human-centred view of food and nutrition, taking into account governance, food production, health, land, labour, environment, knowledge and skills, and trade and finance ${ }^{(47)}$. Lessons learned from these initiatives could help inform Australian policy.

\section{Barriers and enablers faced by policy actors}

The majority of respondents reported conflicting agendas among stakeholders to be a barrier in creating a healthy, safe and sustainable food system. For example, qualitative responses from Round 1 reflect criticisms of the National Food Plan indicating that respondents feel that economic development predominates over other outcomes as a political priority ${ }^{(43)}$. There were a couple of contradictions between identified barriers and enablers in achieving a healthy, sustainable and safe food system. For example, while 'Environmental sustainability not focused on in the Australian Dietary Guidelines' was viewed as a barrier by $71.4 \%$ of participants (health sector only), $85.7 \%$ of participants agreed that the Australian Dietary Guidelines were still an enabler to promoting a healthy, sustainable and safe food system. In addition, despite a lack of consumer awareness being agreed upon as a significant barrier, increasing consumer awareness and support around healthier food environments was considered an enabler by many (92.9\%). This may indicate that respondents feel that consumers are aware that their immediate food environment needs improving, however they may not be aware of the systemic changes required nor what actions that they can take to support this. In addition, consumers need to be motivated, able and given the opportunity to make healthy and sustainable food choices as described by the motivation-ability-opportunity framework $^{(48)}$. Respondents did not appear to consider more distal, but perhaps more significant threats such as climate change, lack of resources, lack of biodiversity, food waste or the growing population as barriers to a healthy, sustainable and safe food system. This may reflect the framing of the current survey questioning around the respondent's current role. 


\section{Study strengths and limitations}

To the authors' knowledge, the present study is the first conducted to examine policy makers' definition of a healthy, safe and sustainable food system in Australia. The study used a Delphi survey to explore consensus and disagreement among multisectoral and multilevel policy makers. The study limitations include a lack of federallevel representation, the high proportion of respondents from the health sector and the lack of representation from other relevant sectors such as trade. There may have also been self-selection bias in that only policy makers interested in the issue may have responded. While the survey examined how policy actors define a healthy, sustainable and safe food system, it did not examine whether they believe achieving such a system is feasible or realistic. In addition, further Delphi rounds and qualitative work would have allowed for a deeper exploration of responses.

\section{Conclusion}

Despite cross-sectoral differences in definitions and contributions evident from the present study's findings, a critical consensus was reached on the definition of a healthy and sustainable food system and how policy makers could contribute to such a system. The definitions covered all of the key issues of nutrition, environmental sustainability and food safety. Perhaps unsurprisingly, the findings indicate that those working in the health sector defined a sustainable and safe food system in terms of population access to healthy, safe, fresh food, while those working in the environment sector were more focused on environmental sustainability. Definitions which achieved critical consensus related to food processing regulation, environmentally friendly food production and nutritious food access. While the definitions lacked the holistic narrative of the $\mathrm{FAO}$, it was promising to find a consensus that respondents could contribute to a healthy, sustainable and safe food system at each stage of the food system, from production to consumption. All policy actors agreed that they played an important role in working to improve access and supply of healthy foods and applying healthy planning principles. While Australia is deemed to have many enabling factors to support a healthy, sustainable and safe food system, the barriers identified in the current study highlight an opportunity to better engage stakeholders, including consumers, in developing healthy, safe and sustainable food systems. Overall, the findings may indicate that a system-wide food and nutrition policy could be developed to meet today's environmental, health, social and economic challenges; however, further research using a more representative multisectoral sample is warranted. While the study focused on the perceptions of policy actors in Australia, it is recommended that other countries examine the definition of healthy, safe and sustainable food systems relevant to their own populations and geographies, in order to advance commitments to the Sustainable Development Goals.

\section{Acknowledgements}

Acknowledgements: The authors would like to acknowledge all of the participants involved. Financial support: This work was supported by The Marie Bashir Institute and The Charles Perkins Centre Healthy Food Systems Node, The University of Sydney. The funders had no role in the design, analysis or writing of this article. Conflict of interest: None. Authorship: S.B. initially conceptualised the research and led the writing of this manuscript. E.S. conducted the research including data collection and analysis. All authors provided input during project development, analysis and write-up of the research. All authors have approved this manuscript for submission. Ethics of human subject participation: This study was conducted according to the guidelines laid down in the Declaration of Helsinki and all procedures involving human subjects were approved by the Human Research Ethics Committee at The University of Sydney (reference number 2016/1024). Written informed consent was obtained from all subjects.

\section{References}

1. High Level Panel of Experts on Food Security and Nutrition (2012) Food Security and Climate Change. A Report by the High Level Panel of Experts on Food Security and Nutrition of the Committee on World Food Security. Rome: FAO.

2. High Level Panel of Experts on Food Security and Nutrition (2014) Food Losses and Waste in the Context of Sustainable Food Systems. Report by the High Level Panel of Experts on Food Security and Nutrition of the Committee on World Food Security. Rome: FAO.

3. High Level Panel of Experts on Food Security and Nutrition (2017) Nutrition and Food Systems. A Report by the High Level Panel of Experts on Food Security and Nutrition of the Committee on World Food Security. Rome: FAO.

4. Reisch L, Eberle U \& Lorek S (2013) Sustainable food consumption: an overview of contemporary issues and policies. Sustainability Sci Pract Policy 9, 7-25.

5. United Nations (2015) Transforming Our World: The 2030 Agenda For Sustainable Development, A/RES/70/1. New York: UN.

6. Global Burden of Disease 2016 Risk Factors Collaborators (2016) Global, regional, and national comparative risk assessment of 84 behavioural, environmental and occupational, and metabolic risks or clusters of risks, 1990-2016: a systematic analysis for the Global Burden of Disease Study 2016. Lancet 390, 1345-1422.

7. Friel S, Dangour AD, Garnett T et al. (2009) Public health benefits of strategies to reduce greenhouse-gas emissions: food and agriculture. Lancet 374, 2016-2025.

8. Henchion M, Hayes M, Mullen AM et al. (2017) Future protein supply and demand: strategies and factors influencing a sustainable equilibrium. Foods $\mathbf{6}, 53$.

9. Ravallion M \& Chen S (2007) China's (uneven) progress against poverty J Dev Econ 82, 1-42.

10. Parfitt C (2013) Confronting corporate power in the food system. https://theconversation.com/confronting-corporatepower-in-the-food-system-9108 (accessed September 2018).

11. Australian Bureau of Statistics (2010) Year Book Australia, 2009-10. http://www.abs.gov.au/AUSSTATS/abs@.nsf/Lookup/ 1301.0main\%20features12009-10 (accessed September 2018). 
12. Hughes L, Steffen W, Rice M et al. (2015) Feeding a Hungry Nation: Climate Change, Food and Farming in Australia. Potts Point, NSW: Climate Council of Australia Ltd.

13. Institute for Health Metrics and Evaluation (2013) GBD Profile: Australia. Seattle, WA: Institute for Health Metrics and Evaluation.

14. Sacks G \& Food-EPI Australia project team (2017) Policies for Tackling Obesity and Creating Healthier Food Environments: Score Card and Priority Recommendations for the Australian Federal Government. Melbourne, VIC: Deakin University.

15. Prime Minister's Science Engineering and Innovation Council (2010) Australia and Food Security in a Changing World. Canberra, ACT: Prime Minister's Science Engineering and Innovation Council.

16. Australian Bureau of Statistics (2012) Australian Social Trends, December 2012. Australian Farming and Farmers. http://www.abs.gov.au/AUSSTATS/abs@.nsf/Lookup/4102. 0Main+Features10Dec+2012 (accessed September 2018).

17. Food and Agriculture Organization of the United Nations (1996) World Food Summit, Declaration on World Food Security. Rome: FAO.

18. Australian Bureau of Statistics (2015) Australian Aboriginal and Torres Strait Islander Health Survey: Nutrition Results Food and Nutrients, 2012-13. Canberra, ACT: Australian Bureau of Statistics.

19. Public Health Association of Australia (2012) A Future for Food 2. Healthy. Sustainable. Fair. Canberra, ACT: Public Health Association of Australia.

20. Food and Agriculture Organization of the United Nations (2010) Sustainable Diets and Biodiversity: Directions and Solutions for Policy, Research and Action. Rome: FAO.

21. Shiffman J \& Smith S (2007) Generation of political priority for global health initiatives: a framework and case study of maternal mortality. Lancet 370, 1370-1379.

22. Association of Public and Land-grant Universities (2016) The Challenge of Change. Washington, DC: Association of Public and Land-grant Universities.

23. de Meyrick J (2003) The Delphi method and health research. Health Educ 103, 7-16.

24. Hsu CC \& Sandford BA (2007) The Delphi technique: making sense of consensus. Pract Assess Res Eval 12, issue 10, http:// pareonline.net/pdf/v12n10.pdf.

25. Allen T, Prosperi P, Cogill B et al. (2018) A Delphi approach to develop sustainable food system metrics. Soc Indic Res 141, 1307-1339.

26. Dalal S, Khodyakov D, Srinivasan R et al. (2011) ExpertLens: a system for eliciting opinions from a large pool of noncollocated experts with diverse knowledge. Technol Forecast Soc Change 78, 1426-1144.

27. Elmer F, Seifert I, Kreibich H et al. (2010) A Delphi method expert survey to derive standards for flood damage data collection. Risk Anal 30, 107-124.

28. Landeta J \& Barrutia J (2011) People consultation to construct the future: a Delphi application. Int J Forecast 27, 134-151.

29. Hasson F, Keeney S \& McKenna H (2000) Research guidelines for the Delphi survey technique. J Adv Nurs 32, 1008-1015.

30. Morgan D (2008) Snowball sampling. In The SAGE Encyclopedia of Qualitative Research Methods, pp. 816-817 [L Given, editor]. Thousand Oaks, CA: SAGE Publications, Inc.
31. National Health and Medical Research Council (2013) Australian Dietary Guidelines. Canberra, ACT: NHMRC.

32. Hendrie GA, Baird D, Ridoutt B et al. (2016) Overconsumption of energy and excessive discretionary food intake inflates dietary greenhouse gas emissions in Australia. Nutrients 8, 690.

33. Gerber PJ, Steinfeld H, Henderson B et al. (2013) Tackling Climate Change Through Livestock - A Global Assessment of Emissions and Mitigation Opportunities. Rome: FAO.

34. Dibb S (2013) Adopting Healthy, Sustainable Diets: Key Opportunities and Barriers. Woking: WWF.

35. Van Loo EJ, Hoefkens C \& Verbeke W (2017) Healthy, sustainable and plant-based eating: perceived (mis)match and involvement-based consumer segments as targets for future policy. Food Policy 69, 46-57.

36. Australian Bureau of Statistics (2016) Australian Demographic Statistics, June 2016. http://www.abs.gov.au/ausstats/ abs@.nsf/Previousproducts/3101.0MainFeatures2Jun2016? opendocument\&tabname $=$ Summary $\&$ prodno $=3101.0 \&$ issue $=J u n \% 202016 \&$ num $=\& v i e w=$ (accessed September 2018).

37. Department of Agriculture, Fisheries and Forestry (2012) Resilience in the Australian Food Supply Chain. Canberra, ACT: Commonwealth of Australia.

38. Garnett T (2014) What is a Sustainable Healthy Diet? A Discussion Paper. Oxford: Food Climate Research Network.

39. Department of Health (2016) Healthy Food Partnership. http:// www.health.gov.au/internet/main/publishing.nsf/content/ healthy-food-partnership (accessed September 2018).

40. World Cancer Research Fund International (2017) NOURISHING framework. http://www.wcrf.org/int/policy/ nourishing-framework (accessed September 2018).

41. Donovan J, Larsen K \& McWhinnie JA (2011) Food-Sensitive Planning and Urban Design: A Conceptual Framework for Achieving a Sustainable and Healthy Food System. Melbourne, VIC: National Heart Foundation of Australia Victorian Division.

42. Commonwealth of Australia (2015) Agricultural Competitiveness White Paper. Canberra, ACT: Commonwealth of Australia.

43. Carey R, Caraher M, Lawrence M et al. (2016) Opportunities and challenges in developing a whole-of-government national food and nutrition policy: lessons from Australia's National Food Plan. Public Health Nutr 19, 3-14.

44. Commonwealth Department of Health Housing and Community Services (1992) Food and Nutrition Policy. Canberra, ACT: Australian Government Publishing Service.

45. National Health and Medical Research Council (2013) Appendix G: Food, nutrition and environmental sustainability. In Australian Dietary Guidelines. Canberra, ACT: NHMRC.

46. Parfitt C, Rose N, Green C et al. (2013) The People's Food Plan. A Common-Sense Approach to a Fair, Sustainable and Resilient Food System. Canberra, ACT: Australian Food Sovereignty Alliance.

47. A People's Food Policy: Transforming our Food System (2017) A People's Food Policy press release. https://www. peoplesfoodpolicy.org/ (accessed July 2019).

48. Grunert KG, Hieke S \& Wills J (2014) Sustainability labels on food products: consumer motivation, understanding and use. Food Policy 44, 177-189. 